\title{
Effect of undegradable intake protein supplementation on urea kinetics and microbial use of recycled urea in steers consuming low-quality forage
}

\author{
Tryon A. Wickersham $\dagger$, Evan C. Titgemeyer*, Robert C. Cochran and Erin E. Wickersham $\dagger$ \\ Department of Animal Sciences and Industry, Kansas State University, Manhattan, KS 66506, USA \\ (Received 4 June 2007 - Revised 10 April 2008 - Accepted 22 April 2008 - First published online 23 May 2008)
}

We evaluated the effect of undegradable intake protein (UIP) on urea kinetics and microbial incorporation of urea-N in ruminally and duodenally fistulated steers $(n 4 ; 319 \mathrm{~kg})$ provided ad libitum access to grass hay in a $4 \times 4$ Latin square. Casein was continuously infused abomasally in amounts of $0,62,124$ and $186 \mathrm{mg} \mathrm{N} / \mathrm{kg}$ body weight per $\mathrm{d}$ to simulate provision of UIP. Periods were $13 \mathrm{~d}$ long with $7 \mathrm{~d}$ for adaptation and $6 \mathrm{~d}$ for collection. Jugular infusion of $\left[{ }^{15} \mathrm{~N}^{15} \mathrm{~N}\right]$ urea followed by determination of urinary enrichment of $\left[{ }^{15} \mathrm{~N}^{15} \mathrm{~N}\right]$ urea and $\left[{ }^{14} \mathrm{~N}^{15} \mathrm{~N}\right]$ urea was used to measure urea kinetics. Forage and $\mathrm{N}$ intake increased (quadratic, $P<0.02$ ) with increasing UIP. Urea synthesis was $27.1,49.9,82.2$ and $85.8 \mathrm{~g}$ urea-N/d for $0,62,124$ and 186 diets, respectively (linear, $P<0.01$ ). The proportion of urea synthesis that entered the gastrointestinal tract was 0.96 for steers receiving no UIP and decreased linearly $(P=0.05)$ to a low of 0.89 for steers receiving 186 . The amount of urea entering the gastrointestinal tract was least for 0 (26.3) and increased (linear, $P<0.01$ ) to $48.7,77.2$ and $76.6 \mathrm{~g}$ urea-N/d for 62,124 and 186 diets, respectively. Microbial incorporation of recycled urea-N increased quadratically $(P=0.04)$ from 13.9 for 0 to $47.7 \mathrm{~g} N / \mathrm{d}$ for 124 . The proportion of microbial $\mathrm{N}$ derived from recycled urea increased (quadratic, $P=0.05$ ) from 0.31 to 0.58 between 0 and 124 and dropped to 0.44 for $186 \mathrm{mg}$ $\mathrm{N} / \mathrm{kg}$ body weight per $\mathrm{d}$. UIP increased intake of hay and provided a $\mathrm{N}$ source for ruminal microbes via urea recycling.

Cattle: Urea recycling: Protein: Supplementation

Protein supplementation to cattle is recommended when there is insufficient ruminally available $\mathrm{N}$ (RAN) to allow for adequate microbial activity for use of fermentable organic matter (OM). The ability of undegradable intake protein (UIP), provided by either forage or supplement, to provide RAN via urea recycling is not considered by many current feeding systems. For example, Level 1 of the National Research Council's Nutrient Requirements of Beef Cattle ${ }^{(1)}$ recommends feeding cattle $130 \mathrm{~g}$ degradable intake protein (DIP)/kg total digestible nutrients, giving no credit for the possible contribution of $\mathrm{N}$ to the RAN pool from the recycling of $\mathrm{N}$ originally supplied as UIP. Ultimately, this leads to an underestimation of RAN when the diet contains significant amounts of UIP. For example, when bermudagrass hay was fed to steers, there was no improvement in forage use when protein was supplemented ${ }^{(2)}$, although the DIP to digestible $\mathrm{OM}$ ratio predicted inadequate amounts of $\mathrm{RAN}^{(1)}$. The authors ${ }^{(2)}$ attributed the lack of response to the UIP in the hay providing RAN through recycling of urea to the rumen. Furthermore, Level 2 of the National Research Council's Nutrient Requirements of Beef Cattle ${ }^{(1)}$ bases its estimate of urea recycling to the rumen solely on the percentage of crude protein in the diet. This assumes that urea recycling is not influenced by protein degradability.
When DIP is supplemented, increases in ruminal ammonia concentration are apparent, but there are only small increases in ruminal ammonia concentration with UIP supplementation ${ }^{(3,4)}$. However, UIP supplementation increases plasma urea concentrations similarly to DIP supplementation ${ }^{(3,4)}$. The combination of lower ruminal ammonia concentrations and similar plasma urea concentrations with UIP supplementation relative to DIP supplementation would be expected to lead to greater urea recycling to the rumen with UIP supplementation ${ }^{(5)}$.

Given the increasing availability of byproducts containing large amounts of UIP (e.g. distiller's grains), knowledge of the contribution of $\mathrm{N}$ recycling to RAN will aid appropriate incorporation of byproducts into supplementation strategies. Previous research has demonstrated that UIP is effective, although less so than DIP, in stimulating intake and digestion of low-quality forage $\mathrm{e}^{(3,4)}$. The mode of action of this increase in intake has not been completely defined. A portion of the response may be due to improved protein status of the animal $^{(6)}$, but much evidence points to the role $\mathrm{N}$ recycling plays in stimulating intake; ruminal ammonia and plasma urea concentrations both increase when supplemental UIP is provided. By accounting for urea-recycling mechanisms, we can better predict the contribution of UIP to RAN, which will allow more accurate prediction of animal response to

Abbreviations: ADIA, acid-detergent insoluble ash; BW, body weight; DIP, degradable intake protein; OM, organic matter; RAN, ruminally available nitrogen;

TDOMI, total digestible organic matter intake; UIP, undegradable intake protein.

* Corresponding author: Dr Evan C. Titgemeyer, fax +1 785 5325681, email etitgeme@ksu.edu

$\dagger$ Present address: Texas A\&M University, College Station, TX 77843 , USA. 
supplemental protein. The objective of the present study was to determine the effect of supplemental UIP on urea kinetics and the microbial incorporation of recycled urea- $\mathrm{N}$.

\section{Experimental methods}

Four duodenally and ruminally fistulated Angus $\times$ Hereford steers (average initial body weight (BW) 319 (SD 17) $\mathrm{kg}$ ) were used in a $4 \times 4$ balanced Latin square to evaluate the effect of increasing amounts of supplemental UIP on urea kinetics and recycled urea- $\mathrm{N}$ use by ruminal microbes in steers consuming low-quality forage. All data from one steer for one period (i.e. one observation) were lost due to problems not related to treatment. The experimental protocol was approved by the Institutional Animal Care and Use Committee at Kansas State University. Steers were provided ad libitum access to fresh water and a trace mineral/salt block (composition: $\geq 96.0 \% \mathrm{NaCl}, 0.16 \% \mathrm{Fe}, 0.40 \% \mathrm{Zn}, 0.32 \% \mathrm{Mn}$, $0.01 \%$ I, $0.04 \% \mathrm{Cu}, 0.004 \%$ Co; American Stockman, Overland Park, KS, USA) while being offered tallgrassprairie hay (i.e. native pasture dominated by big bluestem (Andropogon gerardii), indiangrass (Sorghastrum nutans), little bluestem (Schizachyrium scoparium) and switchgrass (Panicum virgatum)) at 06.30 hours each day (Table 1) at $130 \%$ of average voluntary intake for the preceding $4 \mathrm{~d}$.

Treatments were one of four amounts $(0,62,124$ and $186 \mathrm{mg}$ $\mathrm{N} / \mathrm{kg} \mathrm{BW}$ per d) of casein (Alanate 180, New Zealand Milk Products Inc., Santa Rosa, CA, USA; Table 1) continuously infused abomasally, via infusion lines passed through the rumen cannula and the reticulo-omasal orifice and anchored in the abomasum with a $10 \mathrm{~cm}$ rubber flange. The allotted amount of casein for each treatment was dissolved daily by mixing the casein with 4.5 litres of deionized water for $20 \mathrm{~h}$. Steers receiving no supplement were infused with 4.5 litres deionized water/d. Infusions into the abomasum were accomplished using a peristaltic-pump and polyvinyl chloride tubing. Casein was selected as the supplemental UIP because of its high protein content and high intestinal digestibility. The highest amount of supplemental UIP (186 mg N/kg BW per d) was close to the DIP requirement for maximum forage use ${ }^{(4)}$.

Experimental procedures used general methodologies and adaptation periods validated by Wickersham ${ }^{(7)}$. Experimental periods were $13 \mathrm{~d}$ long, with $7 \mathrm{~d}$ for adaptation to treatments and $6 \mathrm{~d}$ for collection. For the first $4 \mathrm{~d}$ of adaptation, steers were housed in individual pens $(1.5 \times 3.1 \mathrm{~m})$ and tethered to the front of the pen to prevent removal of the abomasal infusion lines. For the remainder of the adaptation and throughout the collection period, steers were placed in metabolism crates to facilitate the total collection of acidified urine and faeces and the jugular infusion of $\left[{ }^{15} \mathrm{~N}^{15} \mathrm{~N}\right]$ urea. Metabolism crates were designed such that urine was collected into a funnel

Table 1. Chemical composition of grass hay and casein ( $\mathrm{g} / \mathrm{kg} \mathrm{DM})$

\begin{tabular}{lcc}
\hline Item & Grass hay & Casein \\
\hline Organic matter & 913 & 957 \\
Crude protein & 47 & 964 \\
Neutral-detergent fibre & 727 & - \\
Acid-detergent fibre & 436 & - \\
Acid-detergent insoluble ash & 55 & - \\
\hline
\end{tabular}

directly beneath the mid portion of the steer and subsequently was diverted into a bucket using gravity, whereas faeces were collected in a pan placed directly behind the steer.

On day 9 at 16.00 hours an indwelling catheter was placed in the jugular vein of each steer to infuse $\left[{ }^{15} \mathrm{~N}^{15} \mathrm{~N}\right]$ urea for the determination of urea kinetics. The catheter was inserted on the evening prior to the start of infusions so that infusions would minimize disturbances in the animals' routine. The $\left[{ }^{15} \mathrm{~N}^{15} \mathrm{~N}\right]$ urea solution was prepared by combining $1.20 \mathrm{~g}$ $\left[{ }^{15} \mathrm{~N}^{15} \mathrm{~N}\right]$ urea $\left(99.7 \%\left[{ }^{15} \mathrm{~N}^{15} \mathrm{~N}\right]\right.$ urea; Medical Isotopes Inc., Pelham, NH, USA) with 1 litre of sterile saline solution $(9 \mathrm{~g} / \mathrm{l} \mathrm{NaCl})$, and then it was filter sterilized $(0.22 \mu \mathrm{m}$ filter unit; Sterivex, Millipore Corporation, Billeric, MA, USA). Saline solution was infused continuously to prevent blockage of the catheter from the time the catheter was placed until 06.00 hours on day 10 when infusion of the $\left[{ }^{15} \mathrm{~N}^{15} \mathrm{~N}\right]$ urea solution began. The $\left[{ }^{15} \mathrm{~N}^{15} \mathrm{~N}\right]$ urea solution was continuously infused until the end of the experimental period at approximately $4 \mathrm{ml} / \mathrm{h}$, which delivered $0.154 \mathrm{mmol}$ urea-N/h, using a syringe infusion pump (Harvard Apparatus, South Natick, MA, USA). Total collections of urine and faeces from day 9 were used to determine background enrichments of ${ }^{15} \mathrm{~N}$. Total collections of urine and faeces from day 12 were used to measure enrichments for calculating urea kinetics. On day 13, rumen fluid samples were collected by suction strainer (19 $\mathrm{mm}$ diameter, $1.5 \mathrm{~mm}$ mesh) just before feeding $(0 \mathrm{~h})$ and at $4,8,12,16$ and $20 \mathrm{~h}$ after feeding. Ruminal fluid $(4 \mathrm{ml})$ from each collection was combined with $1 \mathrm{ml}$ $1 \mathrm{M}-\mathrm{HCl}$ and frozen for ammonia and SCFA analysis. On day 13 , whole ruminal contents $(1 \mathrm{~kg})$ and duodenal samples $(300 \mathrm{ml})$ were collected prior to feeding $(0 \mathrm{~h})$ and at 4,8 , 12,16 and $20 \mathrm{~h}$ after feeding to determine duodenal flows and incorporation of recycled urea- $\mathrm{N}$ into microbial protein. To isolate ruminal bacteria from the whole ruminal contents, 0.5 litres $9 \mathrm{~g} / 1 \mathrm{NaCl}$ solution was added immediately after the sample was collected, then it was blended ( $5 \mathrm{~min}$; Waring Commercial Blender, Waring Commercial, Torrington, CT, USA) and strained through two layers of cheesecloth. The liquid fraction was immediately frozen and the material remaining in the cheesecloth was placed in the rumen. Blood was collected from the jugular vein opposite the catheter into heparinized Vacutainer tubes (Becton Dickinson, Franklin Lakes, NJ, USA) $12 \mathrm{~h}$ after feeding on day 13. Samples were placed in ice water immediately after collection and centrifuged at $5000 \mathrm{~g}$ for $15 \mathrm{~min}$ within $1 \mathrm{~h}$ after collection. Plasma was frozen for subsequent determination of plasma urea-N concentration.

Calculations of intake, digestion and $\mathrm{N}$ balance were made from observations on days 8-12. Feed and ort samples were collected on days 8-11 to correspond with faecal and urine samples collected on days 9-12. Duodenal flows were based on samples from day 13 with acid- detergent insoluble ash (ADIA) serving as an internal marker. Hay was sampled as it was being fed with $400 \mathrm{~g}$ hay retained each day for later analysis. Orts were removed at 06.00 hours and approximately $200 \mathrm{~g}$ were retained for analysis. Faecal bins and urine buckets were removed and contents weighed at 06.15 hours daily. Faeces collected over each $24 \mathrm{~h}$ period were thoroughly mixed, and $3 \%$ was sampled and frozen $\left(-20^{\circ} \mathrm{C}\right)$ for subsequent analysis. Urine collected over each $24 \mathrm{~h}$ period was thoroughly mixed and $2 \%$ was retained as a sample and subsequently 
frozen $\left(-20^{\circ} \mathrm{C}\right)$. Urine $\mathrm{pH}$ was maintained below 3 by adding $400 \mathrm{ml} 6 \mathrm{M}-\mathrm{HCl}$ to urine containers prior to collection.

\section{Laboratory analyses}

Partial DM of hay, ort and faecal (used for faecal output determination) samples was determined by drying at $55^{\circ} \mathrm{C}$ for $96 \mathrm{~h}$ in a forced-air oven. Duodenal samples were frozen and lyophilized. Subsequently, all dried samples were ground with a Wiley mill to pass a $1 \mathrm{~mm}$ screen. Hay and casein samples collected during the measurement phase were pooled across days on an equal weight basis. Ort and faecal samples were composited by steer across days for each period on a proportional basis. Hay, supplement, ort, faecal and duodenal samples were dried for $24 \mathrm{~h}$ at $105^{\circ} \mathrm{C}$ in a forced-air oven to determine DM and then combusted for $8 \mathrm{~h}$ at $450^{\circ} \mathrm{C}$ in a muffle furnace for $\mathrm{OM}$ determination. $\mathrm{N}$ content of hay, casein, wet faeces, urine and duodenal digesta was determined by total combustion (Nitrogen Analyzer Model FP-2000; Leco Corporation, St. Joseph, MI, USA). Crude protein was calculated as $\mathrm{N} \times 6 \cdot 25$. All hay, ort, faecal and duodenal samples were analysed for neutral-detergent fibre and acid-detergent fibre with the ANKOM-Fiber Analyzer (ANKOM-Technology, Fairport, NY, USA) with sodium sulphite and amylase omitted and without correction for residual ash. To determine ADIA of hay, ort, faecal and duodenal samples, the ANKOM bags containing the acid-detergent fibre residues were combusted for $8 \mathrm{~h}$ at $450^{\circ} \mathrm{C}$ in a muffle furnace. Dry faecal and duodenal samples were analysed for ${ }^{15} \mathrm{~N}$ using a stable isotope elemental analyser (Thermofinnigan Delta Plus; Thermo Electron Corporation, Waltham, MA, USA). To isolate ruminal bacteria, samples of ruminal contents were thawed and feed particles were removed from the sample by centrifugation at $500 \mathrm{~g}$ for $20 \mathrm{~min}$. Supernatants were then centrifuged at $20000 \mathrm{~g}$ for $20 \mathrm{~min}$ to pellet the bacteria. The pellet was resuspended with $9 \mathrm{~g} / \mathrm{l} \mathrm{NaCl}$ and centrifuged at $20000 \mathrm{~g}$ for $20 \mathrm{~min}$. The bacterial pellets were frozen and lyophilized. Bacteria were analysed for ${ }^{15} \mathrm{~N}$ enrichment.

For determination of urea kinetics, urinary urea and ammonia concentrations were determined on urine samples collected on days 9 and 12 colorimetrically with an auto-analyser (Technicon Analyzer II; Technicon Industrial Systems, Buffalo Grove, IL, USA) using the methods of Marsh et al. ${ }^{(8)}$ and Broderick \& Kang ${ }^{(9)}$. To remove ammonia from the urine samples initially, $2 \mathrm{ml}$ Dowex 50W-X8 ion exchange resin 100-200 mesh, $\mathrm{H}^{+}$form (Sigma Chemical Co., St. Louis, MO, USA) was mixed with $10 \mathrm{ml}$ urine, vortexed for $15 \mathrm{~s}$ and allowed to stand for $15 \mathrm{~min}$. From the tube, $31 \mu \mathrm{mol}$ urea was pipetted on to a column containing $2 \mathrm{ml}$ Dowex resin to remove any remaining ammonia, and the effluent was discarded. Deionized water $(20 \mathrm{ml})$ was added to the column, and the effluent was discarded ${ }^{(10)}$. An additional $10 \mathrm{ml}$ deionized water was added to the column, and the effluent was retained. Urea and ammonia concentrations of the retained effluent were determined as previously described. If no ammonia was present, then $3 \mu \mathrm{mol}$ urea were transferred into an Exetainer tube (Labco International, Houston, TX, USA), and the sample was brought to $4 \mathrm{ml}$ with deionized water and subsequently frozen. If ammonia was present, the initial step of mixing the urine with the Dowex resin was repeated until no ammonia was present in the final effluent. To prepare samples for Hoffman degradation, He was bubbled through the samples for approximately 10 min, capped and quickly frozen in liquid $\mathrm{N}_{2}$. After freezing, $0.5 \mathrm{ml}$ hypobromite $(27 \mathrm{~g}$ bromine $/ 100 \mathrm{ml} 40 \%$ (w/w) $\mathrm{NaOH})$ was added and the lid screwed on ${ }^{(11)}$. With the tube remaining in liquid $\mathrm{N}_{2}$, a vacuum pump was used to remove the gas from the head space and He was added; this process was repeated three times. After the final addition of $\mathrm{He}$, the Exetainer was removed from liquid $\mathrm{N}_{2}$ and allowed to thaw at room temperature. The thawed sample was then placed in a $60^{\circ} \mathrm{C}$ water-bath for $15 \mathrm{~min}$ to allow the Hoffman degradation reaction to occur rapidly. Samples were then analysed for ${ }^{28} \mathrm{~N}_{2},{ }^{29} \mathrm{~N}_{2}$ and ${ }^{30} \mathrm{~N}_{2}$ using a stable isotope gas bench (Thermofinnigan Delta Plus).

Ruminal SCFA were determined by GLC as described by Vanzant \& Cochran ${ }^{(12)}$. Colorimetric determinations of ruminal ammonia ${ }^{(9)}$ and plasma urea ${ }^{(8)}$ were made using an auto-analyser (Technicon Analyzer II).

\section{Calculations}

Urea kinetics were calculated as outlined by Lobley et al. ${ }^{(13)}$ and include correction $(0.56 \%)$ for non-monomolecular reactions during the Hoffman degradation. This correction was based on standards analysed at the same urea concentration $(0.75 \mathrm{~mm})$ as the samples and was lower than the correction factor $(4.68 \%)$ reported by Lobley et al. ${ }^{(13)}$. The difference between the correction factors can be accounted for by the fact that our urea concentration was much lower $(0.75 v .9 \mathrm{~mm})$ than theirs and is supported by the observed reduction in non-monomolecular reactions as urea concentration decreases ${ }^{(14)}$. Duodenal flow was calculated by dividing faecal ADIA output (g/d) by the ADIA concentration of duodenal digesta. Bacterial $\mathrm{N}$ flow was calculated by multiplying duodenal $\mathrm{N}$ flow by the ratio of duodenal ${ }^{15} \mathrm{~N}$ enrichment to bacterial ${ }^{15} \mathrm{~N}$ enrichment. The flow of bacterial $\mathrm{N}$ derived from recycled urea-N was calculated by multiplying bacterial $\mathrm{N}$ flow by the ratio of bacterial ${ }^{15} \mathrm{~N}$ enrichment to urinary ${ }^{15} \mathrm{~N}$ enrichment. Urinary ${ }^{15} \mathrm{~N}$ enrichment was determined by converting the urinary urea enrichment measurements used to determine urea kinetics to total ${ }^{15} \mathrm{~N}$ enrichment. UIP flow was determined by subtracting bacterial $\mathrm{N}$ flow from total duodenal $\mathrm{N}$ flow, and there was no correction for the contribution of endogenous $\mathrm{N}$ flow.

\section{Statistical analyses}

Intake, digestion, $\mathrm{N}$ balance, urea kinetics, duodenal flows and plasma urea- $\mathrm{N}$ concentration were analysed using the MIXED procedure of SAS System for Windows Release 8.1 (SAS Institute Inc., Cary, NC, USA). Terms in the model were treatment and period with steer included as a random term. Fermentation profile variables were analysed using the MIXED procedure of SAS. Terms in the model were treatment, period, hour, and hour $\times$ treatment with steer and treatment $\times$ period $\times$ steer included as random terms. The repeated term was hour with treatment $\times$ steer serving as the subject. Compound symmetry was used for the covariance structure. Orthogonal polynomial contrasts (linear, quadratic and cubic) were used to partition treatment sums of squares. 


\section{Results}

Forage $\mathrm{OM}$ and total $\mathrm{OM}$ intake increased quadratically $(P=0.02$; Table 2$)$ in response to supplemental UIP, whereas total digestible OM intake (TDOMI) increased linearly $(P<0.01)$. True ruminal OM digestion and ruminal neutraldetergent fibre digestion were not significantly impacted by increasing UIP supplementation. Similarly, total tract digestibilities of $\mathrm{OM}$ and neutral-detergent fibre were not impacted by increasing UIP. By design, intake of $\mathrm{N}$ increased with supplemental UIP (linear, $P<0 \cdot 01$ ). Correspondingly, faecal and urinary $\mathrm{N}$ excretion increased (linear, $P \leq 0.03$ ) with UIP supplementation. absorption increased (linear, $P<0.01$ ) with increasing UIP supplementation. Retention of $\mathrm{N}$ increased (linear, $P<0.01$ ) from $3.4 \mathrm{~g} \mathrm{~N} / \mathrm{d}$ for $0 \mathrm{mg} \mathrm{N} / \mathrm{kg} \mathrm{BW}$ per $\mathrm{d}$ to $37.8 \mathrm{~g} \mathrm{~N} / \mathrm{d}$ for $186 \mathrm{mg} \mathrm{N} / \mathrm{kg} \mathrm{BW}$ per d. Retention of $\mathrm{N}$ as a fraction of $\mathrm{N}$ intake also increased linearly $(P=0.02)$ in response to UIP.

Urinary urea-N excretion, both as an amount per day and as a fraction of urinary $\mathrm{N}$ excretion, increased with UIP supplementation (linear, $P<0.01$; Table 3). Urinary ammonia was not impacted by treatment. Urea production increased linearly $(P<0.01)$ with increasing delivery of supplemental UIP. The amount of urea entering the gut increased linearly $(P<0.01)$ with increasing UIP supplementation; however, gut entry as a fraction of urea production decreased linearly $(P=0.05)$. The amount and fraction of urea that entered the gut and was subsequently returned to the ornithine cycle was increased (linear, $P<0.01$ ) by increasing UIP. Faecal excretion of recycled urea-N increased (quadratic, $P=0.05$ ) with increasing UIP supplementation. Faecal excretion of recycled urea-N as a fraction of gut entry was not impacted by UIP provision. Provision of supplemental UIP tended to increase (quadratic, $P=0.06$ ) anabolic use of recycled urea-N above that of steers receiving no UIP. Anabolic use of recycled urea-N as a fraction of gut entry decreased (linear, $P<0.01$ ) with increasing supplemental UIP.

Duodenal $\mathrm{N}$ flow, microbial $\mathrm{N}$ flow and UIP flow increased (linear, $P \leq 0.01$; Table 4) with increasing provision of supplemental protein. Incorporation of recycled urea-N by ruminal microbes was increased (quadratic, $P=0.04$ ) by supplemental UIP. The fraction of total microbial $\mathrm{N}$ from recycled urea-N increased quadratically $(P=0.05)$ with increasing levels of supplemental UIP. The fraction of urea production and of urea entering the gut that was incorporated into microbial $\mathrm{N}$ was not significantly impacted by supplemental UIP. Microbial efficiency was not significantly altered by UIP supplementation. Plasma urea-N concentration was linearly $(P<0 \cdot 01$; Table 5$)$ increased by supplemental UIP.

The treatment $\times$ time interaction was significant for ruminal ammonia, but the interaction was largely due to the magnitude of the difference that existed between treatments at different times rather than to changes in treatment rankings (data not shown). Therefore, to facilitate discussion, only treatment means are presented. Ruminal ammonia concentration increased linearly $(P<0 \cdot 01$; Table 5$)$ with increasing supplemental protein, but the magnitude of the increase was small, from 0.08 to $0.55 \mathrm{~mm}$ for 0 and $186 \mathrm{mg} \mathrm{N} / \mathrm{kg}$ $\mathrm{BW}$ per $\mathrm{d}$, respectively. Concentrations of SCFA linearly $(P<0.01)$ increased with increasing UIP supplementation. The molar proportions of acetate, butyrate and valerate were not altered by UIP provision. Propionate proportion was increased quadratically $(P=0 \cdot 01)$ and isobutyrate and isovalerate were linearly $(P<0.01)$ decreased with supplemental UIP. There was a significant treatment $\times$ time interaction for valerate, but data are not shown because the magnitude of the differences were small (all treatments at all time-points ranged between 0.28 and 0.40 molar percentage) and deemed not biologically important. Ruminal $\mathrm{pH}$ was linearly $(P<0 \cdot 01)$ decreased by supplemental UIP.

Table 2. Effects of undegradable intake protein supplementation on intake, digestion and nitrogen balance of steers fed grass hay*

\begin{tabular}{|c|c|c|c|c|c|c|c|c|}
\hline \multirow[b]{2}{*}{ Item } & \multicolumn{4}{|c|}{ Undegradable intake protein (mg N/kg body wt per d) } & \multirow[b]{2}{*}{ SEM $\dagger$} & \multicolumn{3}{|c|}{ Contrast $P$ value } \\
\hline & 0 & 62 & 124 & 186 & & Linear & Quadratic & Cubic \\
\hline No. of observations & 4 & 4 & 3 & 4 & & & & \\
\hline \multicolumn{9}{|l|}{ Organic matter intake $(\mathrm{kg} / \mathrm{d})$} \\
\hline Forage & $6 \cdot 1$ & 6.9 & 7.9 & 7.3 & 0.24 & $<0.01$ & 0.02 & 0.10 \\
\hline Total & $6 \cdot 1$ & $7 \cdot 0$ & $8 \cdot 1$ & $7 \cdot 7$ & 0.24 & $<0.01$ & 0.02 & 0.09 \\
\hline Digestible & 3.7 & $4 \cdot 1$ & 4.8 & 4.6 & 0.21 & $<0.01$ & 0.12 & 0.24 \\
\hline \multicolumn{9}{|l|}{ Ruminal digestibility (g/kg) } \\
\hline Organic matter & 533 & 527 & 520 & 531 & 49 & 0.94 & 0.82 & 0.91 \\
\hline Neutral-detergent fibre & 525 & 526 & 526 & 558 & 64 & 0.59 & 0.72 & 0.87 \\
\hline \multicolumn{9}{|l|}{ Total tract digestibility $(\mathrm{g} / \mathrm{kg})$} \\
\hline Organic matter & 604 & 587 & 581 & 595 & 31 & 0.71 & 0.49 & 0.93 \\
\hline Neutral-detergent fibre & 590 & 559 & 543 & 567 & 34 & 0.40 & 0.25 & 0.80 \\
\hline \multicolumn{9}{|l|}{$N(g / d)$} \\
\hline Intake & $50 \cdot 0$ & $74 \cdot 8$ & 102.4 & $115 \cdot 1$ & $2 \cdot 2$ & $<0.01$ & 0.02 & 0.07 \\
\hline Forage & 50.0 & 56.5 & $65 \cdot 1$ & $60 \cdot 3$ & 2.0 & $<0.01$ & 0.01 & 0.09 \\
\hline Supplement & 0.0 & 18.5 & $37 \cdot 6$ & 54.8 & $1 \cdot 1$ & $<0.01$ & 0.32 & 0.42 \\
\hline Faecal & 24.9 & $33 \cdot 0$ & $40 \cdot 7$ & $41 \cdot 2$ & $2 \cdot 7$ & $<0.01$ & 0.10 & 0.49 \\
\hline Urinary & $21 \cdot 6$ & $24 \cdot 6$ & $31 \cdot 1$ & $36 \cdot 0$ & $4 \cdot 2$ & 0.03 & 0.81 & 0.78 \\
\hline Absorbed & $25 \cdot 0$ & $41 \cdot 7$ & $61 \cdot 8$ & 73.9 & 4.1 & $<0.01$ & 0.48 & 0.47 \\
\hline Retained & 3.4 & $17 \cdot 1$ & 31.8 & 37.8 & $5 \cdot 2$ & $<0.01$ & 0.44 & 0.66 \\
\hline $\mathrm{N}$ retained $/ \mathrm{N}$ intake & 0.07 & 0.23 & 0.30 & 0.33 & 0.07 & 0.02 & 0.31 & 0.94 \\
\hline $\mathrm{N}$ retained/N absorbed & 0.12 & 0.39 & 0.49 & 0.51 & 0.12 & 0.04 & 0.27 & 0.86 \\
\hline
\end{tabular}

*For details of procedures, see Experimental methods.

†For $n 3$. 
Table 3. Effects of undegradable intake protein supplementation on urea excretion, ammonia excretion and urea kinetics in steers fed grass hay*

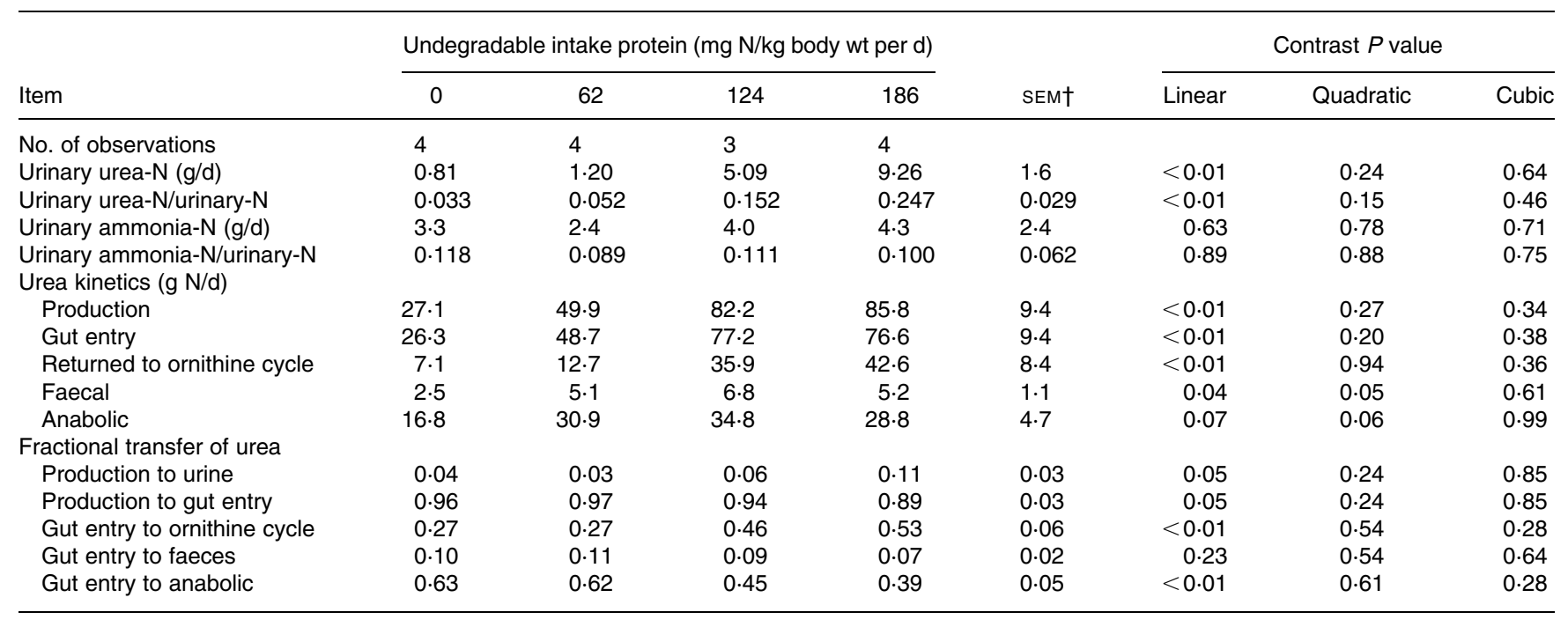

${ }^{*}$ For details of procedures, see Experimental methods.

†For $n 3$.

\section{Discussion}

Intake of low-quality forage responded less in the present study, as a percentage of control, than when the same levels of casein were ruminally supplemented to cattle consuming similar forage ${ }^{(7)}$. Work using similar forages has shown that UIP supplemented at levels near $124 \mathrm{mg} \mathrm{N} / \mathrm{kg} \mathrm{BW}$ per d led to increases in TDOMI that were about two-thirds as great as observed when the same level DIP was supplemented ${ }^{(3,4)}$. They attributed the increases in intake to increased RAN and a possible alleviation of metabolic discomfort with the improvement in protein status. Provision of post-ruminal $\mathrm{N}$ as either casein or urea stimulated intake of low-quality forage in sheep ${ }^{(6,15)}$, although the mechanism of each increase was hypothesized to be different. They observed an increase in digestion rate with urea, but not with casein, leading them to conclude that casein was acting as a chemoregulator, whereas urea was increasing intake via $\mathrm{N}$ recycling mechanisms. Garza et al. ${ }^{(16)}$ also observed increases in low-quality forage intake in cattle with provision of either casein or urea post-ruminally. It is also possible that bioactive peptides in casein impacted gut motility ${ }^{(17-19)}$ and subsequently intake. We attribute the increase in forage intake in the present study predominantly to the increased RAN supply from recycled urea and the subsequent improvement in ruminal fermentation of the forage.

Supplemental UIP did not affect either ruminal or total tract neutral-detergent fibre digestion, which is similar to the lack of effect on digestion of neutral-detergent fibre observed by Bandyk et al. ${ }^{(3)}$ and Wickersham et al. ${ }^{(4)}$ when casein was provided abomasally to steers. In contrast, Egan \& Moir ${ }^{(6)}$ observed a numerical decrease in DM digestion in sheep supplemented with UIP as casein when compared to control or post-ruminal urea provision. Garza et al. ${ }^{(16)}$ observed

Table 4. Effects of undegradable intake protein supplementation on duodenal nitrogen flows and recycled urea-nitrogen incorporation into microbial nitrogen in steers fed grass hay*

\begin{tabular}{|c|c|c|c|c|c|c|c|c|}
\hline \multirow[b]{2}{*}{ Item } & \multicolumn{4}{|c|}{ Undegradable intake protein ( $\mathrm{mg} \mathrm{N} / \mathrm{kg}$ body wt per $\mathrm{d}$ ) } & \multirow[b]{2}{*}{ SEM† } & \multicolumn{3}{|c|}{ Contrast $P$ value } \\
\hline & 0 & 62 & 124 & 186 & & Linear & Quadratic & Cubic \\
\hline No. of observations & 4 & 4 & 3 & 4 & & & & \\
\hline \multicolumn{9}{|l|}{ Duodenal $N$ flow (g N/d) } \\
\hline Total & $80 \cdot 8$ & 113.8 & $161 \cdot 2$ & $161 \cdot 1$ & $14 \cdot 6$ & $<0.01$ & 0.23 & 0.33 \\
\hline Microbial & $45 \cdot 7$ & $65 \cdot 3$ & $81 \cdot 2$ & $75 \cdot 7$ & 7.9 & 0.01 & $0 \cdot 10$ & 0.58 \\
\hline Undegradable intake protein & $35 \cdot 1$ & 48.5 & 79.1 & 85.5 & 7.9 & $<0.01$ & 0.63 & 0.25 \\
\hline \multicolumn{9}{|l|}{ MNU } \\
\hline MNU (g/d) & $13 \cdot 9$ & $28 \cdot 3$ & $47 \cdot 7$ & 33.9 & $6 \cdot 2$ & 0.01 & 0.04 & $0 \cdot 16$ \\
\hline MNU/total microbial $\mathrm{N}$ & 0.31 & 0.42 & 0.58 & 0.44 & 0.06 & 0.05 & 0.05 & 0.19 \\
\hline MNU/urea-N production & 0.53 & 0.57 & 0.58 & 0.41 & 0.07 & 0.21 & $0 \cdot 12$ & 0.64 \\
\hline $\mathrm{MNU} /$ gut entry of urea-N & 0.55 & 0.59 & 0.61 & 0.46 & 0.07 & 0.36 & $0 \cdot 18$ & 0.58 \\
\hline \multicolumn{9}{|l|}{ Microbial efficiency } \\
\hline g N/kg OM fermented $\ddagger$ & 14.5 & $17 \cdot 7$ & $19 \cdot 0$ & $19 \cdot 7$ & 3.6 & 0.24 & 0.69 & 0.92 \\
\hline $\mathrm{g} \mathrm{N} / \mathrm{kg}$ TDOMI§ & $12 \cdot 7$ & $15 \cdot 9$ & $17 \cdot 0$ & $17 \cdot 0$ & 2.5 & 0.17 & 0.47 & 0.94 \\
\hline
\end{tabular}

MNU, microbial $\mathrm{N}$ from recycled urea; OM, organic matter; TDOMI, total digestible organic matter intake.

${ }^{\star}$ For details of procedures, see Experimental methods.

†For $n 3$.

$\ddagger$ Microbial $\mathrm{N}$ flowing to the duodenum per kg of truly digested $\mathrm{OM}$.

$\S$ Microbial $\mathrm{N}$ flowing to the duodenum per $\mathrm{kg}$ of TDOMI. 
Table 5. Effects of undegradable intake protein supplementation on plasma urea-nitrogen concentration and ruminal fermentation characteristics in steers consuming grass hay*

\begin{tabular}{|c|c|c|c|c|c|c|c|c|}
\hline \multirow[b]{2}{*}{ Item } & \multicolumn{4}{|c|}{ Undegradable intake protein (mg N/kg body wt per d) } & \multirow[b]{2}{*}{ SEM† } & \multicolumn{3}{|c|}{ Contrast $P$ value } \\
\hline & 0 & 62 & 124 & 186 & & Linear & Quadratic & Cubic \\
\hline Plasma urea-N (mm) & 0.90 & 1.42 & 2.04 & $2 \cdot 64$ & 0.18 & $<0.01$ & 0.79 & 0.92 \\
\hline \multicolumn{9}{|l|}{ Ruminal fermentation } \\
\hline Ammonia (mм) & 0.08 & 0.12 & 0.32 & 0.55 & 0.09 & $<0.01$ & 0.19 & 0.69 \\
\hline Total SCFA (mm) & $61 \cdot 4$ & $65 \cdot 7$ & $70 \cdot 7$ & $69 \cdot 0$ & $2 \cdot 0$ & $<0.01$ & 0.02 & $0 \cdot 19$ \\
\hline Acetate & 0.77 & 0.77 & 0.77 & 0.77 & 0.004 & 0.15 & 0.31 & 0.58 \\
\hline Propionate & 0.13 & 0.12 & 0.13 & 0.13 & 0.003 & 0.01 & 0.01 & 0.58 \\
\hline Butyrate & 0.09 & 0.09 & 0.09 & 0.09 & 0.002 & 0.08 & 0.11 & 0.66 \\
\hline Isobutyrate & 0.0061 & 0.0056 & 0.0046 & 0.0043 & 0.0002 & $<0.01$ & 0.39 & 0.04 \\
\hline Isovalerate & 0.0047 & 0.0040 & 0.0032 & 0.0029 & 0.0002 & $<0.01$ & 0.09 & 0.37 \\
\hline Valerate & 0.0031 & 0.0031 & 0.0033 & 0.0034 & 0.0002 & 0.15 & 0.52 & 0.77 \\
\hline $\mathrm{pH}$ & $6 \cdot 62$ & 6.58 & $6 \cdot 48$ & 6.49 & 0.043 & $<0.01$ & 0.27 & 0.07 \\
\hline
\end{tabular}

* For details of procedures, see Experimental methods.

†For $n 3$.

greater ruminal DM digestibility when steers were supplemented with either casein or urea post-ruminally compared to control. Digestibility in the present study was likely not improved, in spite of greater microbial activity, because passage increases along with intake in response to higher levels of $\operatorname{RAN}^{(20,21)}$.

In general, $\mathrm{N}$ retention of cattle fed low-quality forage is improved in response to supplemental $\operatorname{protein}^{(7,22,23)}$, but the specific response to supplemental UIP has not been documented. The levels of $\mathrm{N}$ retention $(3.4-37.8 \mathrm{~g} \mathrm{~N} / \mathrm{d})$ in the present study are similar to previous observations of cattle consuming low-quality forage and supplemented with protein. Hennessy \& Nolan ${ }^{(2)}$ observed $\mathrm{N}$ retention of $3.6 \mathrm{~g}$ $\mathrm{N} / \mathrm{d}$ when cattle were fed subtropical grass and not supplemented, and when supplemented (100 mg N/kg BW per d) cattle retained $15.6 \mathrm{~g} \mathrm{~N} / \mathrm{d}$. Supplementation of similar levels of casein as DIP led to a linear increase in $\mathrm{N}$ retention from -2.7 to $35.2 \mathrm{~g} \mathrm{~N} / \mathrm{d}^{(7)}$, which is very similar to the response when UIP was supplemented. In the current study, growth of steers was likely more limited by energy supply than by protein supply, and, thus, the increases in $\mathrm{N}$ retention with UIP provision likely resulted from increases in energy supply rather than from the direct increases in protein supply. The provision of UIP not only increased the energy supply by directly providing a source of digestible amino acids that could be catabolized and used as a source of energy, but also by increasing forage intake as a result of $\mathrm{N}$ from the UIP being recycled to the rumen as urea. The entry of urea- $\mathrm{N}$ into the gut increases energy intake by stimulating ruminal fermentation and increasing forage intake and TDOMI, which is in accordance with the work of Egan \& Moir ${ }^{(6)}$ and Egan ${ }^{(15)}$.

Supplemental UIP increased urinary $\mathrm{N}$ excretion linearly $(P<0.03)$, but the magnitude of the increase in urinary $\mathrm{N}$ excretion was less than the observations of Archibeque et al. ${ }^{(24)}$ and Marini \& Van Amburgh ${ }^{(25)}$ when $\mathrm{N}$ intake was increased. Hunter \& Siebert ${ }^{(22)}$ also reported that supplementation with cottonseed meal resulted in only small increases in urinary $\mathrm{N}$ excretion. Faecal excretion of $\mathrm{N}$ increased somewhat more than urinary $\mathrm{N}$ excretion in response to supplementation, which is also in accordance with the observations of Hunter $\&$ Siebert $^{(22)}$ and Wickersham ${ }^{(7)}$. Increased $\mathrm{N}$ intake in some other work did not increase faecal $\mathrm{N}$ excretion ${ }^{(24-26)}$. Faecal $\mathrm{N}$ excretion in the present study was increased with provision of increasing amounts of $\mathrm{N}$ because microbial growth (ruminal microbial $\mathrm{N}$ that is indigestible in the intestine, intestinally synthesized microbial $\mathrm{N}$ that is directly excreted in faeces, or both) and forage intake were increased, both of which increase the excretion of $\mathrm{N}$ in the faeces. Concomitantly, urinary $\mathrm{N}$ was not greatly increased because additions of $\mathrm{N}$ to our diet were largely used either directly by the steers for protein deposition or conserved by the animal through urea recycling mechanisms and subsequently incorporated into microbial $\mathrm{N}$, which could contribute to both faecal and retained $\mathrm{N}$.

Quantifying urea kinetics and the incorporation of recycled urea-N into ruminal microbial $\mathrm{N}$ with increasing provision of UIP were the primary objectives of the present study. Production of urea increases as $\mathrm{N}$ intake increases ${ }^{(7,27,28)}$. Urea production as a fraction of $\mathrm{N}$ intake was 0.54 when no supplemental protein was provided. When supplemental protein was provided as UIP, urea production as a fraction of $\mathrm{N}$ intake averaged $0 \cdot 74$. In contrast, urea production as a fraction of $\mathrm{N}$ intake was 0.46 when supplemental DIP was provided ${ }^{(7)}$. In further contrast to the present study, urea production as a fraction of $\mathrm{N}$ intake in dairy heifers averaged $0 \cdot 27^{(25)}$ and in steers consuming different grasses it averaged $0 \cdot 28^{(24)}$ and $0.43^{(26)}$. Hennessy \& Nolan ${ }^{(23)}$ reported urea productions as fractions of $\mathrm{N}$ intakes of 0.62 and 0.53 for supplemented and unsupplemented steers, respectively. Urea production as a fraction of $\mathrm{N}$ intake in the present study was higher than other studies because $\mathrm{N}$ was provided in a different form, UIP $v$. DIP. The present observation is, in part, supported by the numerically greater plasma urea-N concentrations observed by Bandyk et al. ${ }^{(3)}$ and Wickersham et al. ${ }^{(4)}$ when equal amounts of casein were supplied as UIP $v$. DIP in cattle consuming low-quality forage. Their reported differences in plasma urea- $\mathrm{N}$ concentrations existed despite significantly greater ruminal ammonia concentrations in both studies when casein was supplied as DIP $v$. UIP. These differences between UIP and DIP occurred for two reasons: (1) when UIP was supplemented, microbes did not have first access to the $\mathrm{N}$, which prevented formation of indigestible 
microbial residues or of products (e.g. purines) for which the end-point of metabolism does not involve urea synthesis (the difference between the present study and Wickersham ${ }^{(7)}$ with DIP supplementation), and (2) energy availability (i.e. forage intake) did not increase as rapidly as metabolizable protein supply resulting in the catabolism of the excess amino acids with the subsequent production of urea which could be recycled to the gut.

Urea can be excreted in the urine or be recycled to the gastrointestinal tract (gut entry). Urinary urea excretion was increased with provision of increasing amounts of UIP, in accordance with observations ${ }^{(7)}$ where increasing DIP provision augmented urinary urea excretion, but fractional urinary excretion was only $0 \cdot 11$ of production at the highest level of supplementation. The low urinary urea excretion despite increased urea production indicates the remarkable ability of cattle to conserve $\mathrm{N}$ through urea recycling mechanisms in the face of a severe $\mathrm{N}$ deficiency. Hennessy \& Nolan ${ }^{(23)}$ and Thornton $^{(29)}$ also reported low excretions of urinary urea: 0.41 and $1.6 \mathrm{~g}$ urea-N/d when cattle were fed carpet grass hay ( $49 \mathrm{~g}$ crude protein $/ \mathrm{kg} \mathrm{DM})$ or oat straw ( $19 \mathrm{~g}$ crude protein/kg DM), respectively. When sheep were fed low-quality forage, the fraction of urinary $\mathrm{N}$ from urea was $0 \cdot 35^{(30)}$. Using a higher-quality forage ( $88 \mathrm{~g}$ crude protein $/ \mathrm{kg} \mathrm{DM})$, Archibeque et al. ${ }^{(24)}$ reported that $0.32-0.55$ of urinary $\mathrm{N}$ excretion was urea. Archibeque et al. ${ }^{(26)}$ reported that $0.66-$ 0.77 of urinary $\mathrm{N}$ excretion was as urea- $\mathrm{N}$ for steers fed tall fescue hay.

Gut entry of urea as a fraction of urea production in the present study ranged from 0.97 to 0.89 , decreasing with UIP supplementation. Urea transfer to the gut at the low levels of supplementation was nearly as high as reported by Wickersham $^{(7)}$ when low levels of DIP were supplemented. Gut entry of urea increased with increasing provision of supplemental protein, but urea transferred to the gut as a fraction of $\mathrm{N}$ intake was greater when steers were supplemented with UIP (current study, 0.69) rather than $\operatorname{DIP}^{(7)}(0.45)$. This likely was because urea production represented a greater proportion of intake when UIP rather than DIP was supplemented, because most of the urea production was recycled to the gut in both studies. Similar to the observations of the present study, high fractional transfers of urea production to the gut $(0.84$ and 0.87$)$ have previously been reported Archibeque et $a l .^{(24)}$ and Marini \& Van Amburgh ${ }^{(25)}$. Additionally, Hennessy \& Nolan ${ }^{(23)}$ reported fractional transfers of urea to the gut of 0.79 and 0.97 in supplemented and unsupplemented steers, respectively. The present study demonstrates that in the face of a RAN deficiency, UIP supplementation can provide a substantial amount of $\mathrm{N}$ to the rumen by increasing urea recycling. The low ruminal ammonia concentrations for all treatments and the increase in microbial protein flow in the face of increasing recycled urea in response to UIP supplementation demonstrate the ability of ruminal microbes to utilize the recycled $\mathrm{N}$ efficiently under the present experimental conditions.

In the present study, anabolic use of urea $(\mathrm{g} \mathrm{N} / \mathrm{d})$ tended to increase (quadratic, $P=0.06$ ) with increasing amounts of supplemental UIP. The difference between the present study and the work of Lobley et al. ${ }^{(13)}$ and Marini \& Van Amburgh $^{(25)}$ is that in the present study provision of additional $\mathrm{N}$ stimulated microbial activity by providing RAN and thereby increased the intake of fermentable OM. The same stimulation of microbes occurred with DIP supplementation ${ }^{(7)}$ except, with DIP supplementation, as more $\mathrm{N}$ became available for $\mathrm{N}$ recycling, the demand for $\mathrm{N}$ from recycling was diminished because of the direct provision of RAN as DIP.

Microbial incorporation of recycled urea-N increased quadratically with increasing supplemental UIP. In contrast, when increasing amounts of DIP were provided, microbial incorporation of recycled urea-N increased linearly ${ }^{(7)}$. Marini $\&$ Van Amburgh ${ }^{(25)}$ observed a decrease in microbial incorporation of recycled urea- $\mathrm{N}$ as $\mathrm{N}$ intake increased in dairy heifers. The fraction of total microbial $\mathrm{N}$ derived from microbial incorporation of recycled urea-N also increased quadratically $(P=0.05)$ in response to increasing UIP in the present study. In contrast, with DIP supplementation ${ }^{(7)}$ there was no change in the fraction of total microbial $\mathrm{N}$ derived from recycled urea-N (average of 0.28). Similar to those observations, Neutze et al. ${ }^{(31)}$ observed that, in sheep fed alkali-treated wheat straw and supplemented with urea, the fraction of microbial $\mathrm{N}$ derived from recycled urea-N was 0.12 and 0.31 for supplemented and unsupplemented sheep, respectively. In cattle fed a low-protein diet, Bunting et al. ${ }^{(28)}$ found that recycled urea-N contributed 0.40 of microbial $\mathrm{N}$. The quadratic response of microbial incorporation of recycled urea-N in the present study is explained by the plateauing of TDOMI, urea production and gut entry of urea when UIP supplementation increased from 124 to $186 \mathrm{mg} \mathrm{N} / \mathrm{kg} \mathrm{BW}$ per d. Between 0 and $124 \mathrm{mg} \mathrm{N} / \mathrm{kg}$ $\mathrm{BW}$ per $\mathrm{d}$, microbial incorporation of recycled urea-N increased by the equivalent of 0.87 of the UIP dose.

In the present calculation of microbial incorporation of recycled urea- $\mathrm{N}$, all of the ${ }^{15} \mathrm{~N}$ appearing at the duodenum was attributed to incorporation of recycled urea-N. In contrast, Ouellet et al. ${ }^{(32)}$ reported that endogenous secretions other than urea accounted for $13 \%$ of duodenal $\mathrm{N}$ flow and that half of this $\mathrm{N}$ was found in microbial $\mathrm{N}$. It is probable in the present study that a portion of the non-urea endogenous secretions would be labelled with ${ }^{15} \mathrm{~N}$, which would inflate our measures of microbial incorporation of recycled urea-N, although differences between our steers fed low-protein diets and their dairy cows fed diets with $17.5 \%$ crude protein would preclude extrapolation of their observations to the present data. In the model used by Ouellet et al. ${ }^{(32)}$ they assumed that 0.12 of the microbial $\mathrm{N}$ was derived from urea- $\mathrm{N}$, which is much less than the fraction of microbial $\mathrm{N}$ from recycled urea- $\mathrm{N}$ in the present study $(0.31-0.58)$, and the length of their ${ }^{15} \mathrm{~N}$ infusion was much longer than ours $(200 v .96 \mathrm{~h})$, which would increase the enrichment of the endogenous secretions. Further work would be required to determine how much ${ }^{15} \mathrm{~N}$ appears as endogenous $\mathrm{N}$ other than urea.

The contribution of recycled urea- $\mathrm{N}$ to meeting ruminal $\mathrm{N}$ requirements was increased as UIP provision increased up to $124 \mathrm{mg} \mathrm{N} / \mathrm{kg} \mathrm{BW}$ per d. Although UIP did not lead to increases in forage intake as large as expected for DIP, it did increase the energy and metabolizable protein supplied to the animal. If protein supplements that are high in UIP are cheaper than protein supplements high in DIP, there is an opportunity to utilize the UIP-containing supplements to increase ruminal $\mathrm{N}$ supply. The present study provides information that can be incorporated into feeding recommendations that will better account for the contributions of UIP to meeting ruminal $\mathrm{N}$ requirements. 


\section{Acknowledgements}

This paper is contribution number 07-287-J from the Kansas Agricultural Experiment Station, Manhattan. Financial support of this research was provided by the Kansas Agricultural Experiment Station. The authors are unaware of any biases or conflicts of interest that may have prejudiced interpretation or presentation of results. T. A. W., E. C. T. and R. C. C. were responsible for developing the original hypothesis, selecting the appropriate experimental design and methodologies, data analysis, and data interpretation. T. A. W. and E. E. W. were responsible for animal care, implementation of the experimental protocol, sample processing and handling, and data processing. All authors contributed to development of the manuscript. The authors gratefully acknowledge Dr Roxane Fagan at North Carolina State University for her assistance in analysing ${ }^{15} \mathrm{~N}$-enriched samples and Cheryl Armendariz at Kansas State University for her assistance in the laboratory.

\section{References}

1. National Research Council (1996) Nutrient Requirements of Beef Cattle, 7th rev. ed. Washington, DC: National Academy Press.

2. Mathis CP, Cochran RC, Heldt JS, Woods BC, Abdelgadir IEO, Olson KC, Titgemeyer EC \& Vanzant ES (2000) Effects of supplemental degradable intake protein on utilization of mediumto low-quality forages. J Anim Sci 78, 224-232.

3. Bandyk CA, Cochran RC, Wickersham TA, Titgemeyer EC, Farmer CG \& Higgins JJ (2001) Effect of ruminal vs postruminal administration of degradable protein utilization of low-quality forage by beef steers. J Anim Sci 79, 225-231.

4. Wickersham TA, Cochran RC, Titgemeyer EC, Farmer CG, Klevesahl EA, Arroquy JI, Johnson DE \& Gnad DP (2004) Effect of postruminal protein supply on the response to ruminal protein supplementation in beef steers fed a low-quality grass hay. Anim Feed Sci Tech 115, 19-36.

5. Kennedy PM \& Milligan LP (1980) The degradation and utilization of endogenous urea in the gastrointestinal tract of ruminants: a review. Can J Anim Sci 60, 205-221.

6. Egan AR \& Moir RJ (1965) Nutritional status and intake regulation in sheep. I. Effects of duodenally infused single doses of casein, urea, and propionate upon voluntary intake of a lowprotein roughage by sheep. Aust J Agric Res 16, 437-449.

7. Wickersham TA (2006) Effect of supplemental protein on nitrogen recycling in beef cattle consuming low-quality forage. $\mathrm{PhD}$ Thesis, Kansas State University.

8. Marsh WH, Fingerhut B \& Miller H (1965) Automated and manual direct methods for the determination of blood urea. Clin Chem 11, 624-627.

9. Broderick GA \& Kang JH (1980) Automated simultaneous determination of ammonia and total amino acids in ruminal fluid and in vitro media. J Dairy Sci 63, 64-75.

10. Read WW, Harrison RA \& Halliday D (1982) A resin-based method for the preparation of molecular nitrogen for ${ }^{15} \mathrm{~N}$ analysis from urinary and plasma components. Anal Biochem 123, 249-254.

11. Volk RJ \& Jackson WA (1979) Preparing nitrogen gas for nitrogen-15 analysis. Anal Chem 51, 463-464.

12. Vanzant ES \& Cochran RC (1994) Performance and forage utilization by beef cattle receiving increasing amounts of alfalfa hay as a supplement to low-quality, tallgrass-prairie forage. $J$ Anim Sci 72, 1059-1067.

13. Lobley GE, Bremner DM \& Zuur G (2000) Effects of diet quality on urea fates in sheep assessed by a refined, non-invasive $\left[{ }^{15} \mathrm{~N}^{15} \mathrm{~N}\right]$-urea kinetics. Br J Nutr 84, 459-468.
14. Marini JC \& Attene-Ramos MS (2006) An improved analytical method for the determination of urea nitrogen isotopomers in biological sample utilizing continuous flow isotope ratio mass spectrometry. Rapid Commun Mass Spectrom 20, $3736-3740$.

15. Egan AR (1965) Nutritional status and intake regulation in sheep. II. The influence of sustained duodenal infusions of casein or urea upon voluntary intake of low-protein roughages by sheep. Aust J Agric Res 16, 451-462.

16. Garza JD, Owens FN \& Welty S (1991) Effect of postruminal protein infusion on feed intake and utilization of low quality hay by beef steers. Okla Agric Exp Sta Res Rep MP-134, $106-113$.

17. Daniel H, Vohwinkel M \& Rehner G (1990) Effect of casein and $\beta$-casomorphins on gastrointestinal motility in rats. $J$ Nutr 120, 252-257.

18. Kil SL \& Froetschel MA (1994) Involvement of opioid peptides from casein on reticular motility and digesta passage in steers. J Dairy Sci 77, 111-123.

19. Froetschel MA (1996) Bioactive peptides in digesta that regulate gastrointestinal function and intake. J Anim Sci 74, $2500-2508$.

20. Köster HH, Cochran RC, Titgemeyer EC, Vanzant ES, Abdelgadir I \& St. Jean G (1996) Effect of increasing degradable intake protein on intake and digestion of low-quality, tallgrass-prairie forage by beef cows. J Anim Sci 74, $2473-2481$.

21. Olson KC, Cochran RC, Jones TJ, Vanzant ES, Titgemeyer EC \& Johnson DE (1999) Effects of ruminal administration of supplemental degradable intake protein and starch on utilization of low-quality warm season grass hay by beef steers. J Anim Sci 77, 1016-1025.

22. Hunter RA \& Siebert BD (1980) The utilization of spear grass (Heteropogon contortus). IV. The nature and flow of digesta in cattle fed on spear grass alone and with protein or nitrogen or sulfur. Aust J Agric Res 31, 1037-1047.

23. Hennessy DW \& Nolan JV (1988) Nitrogen kinetics in cattle fed a mature subtropical grass hay with and without protein meal supplementation. Aust J Agric Res 39, 1135-1150.

24. Archibeque SL, Burns JC \& Huntington GB (2001) Urea flux in beef steers: effects of forage species and nitrogen fertilization. J Anim Sci 79, 1937-1943.

25. Marini JC \& Van Amburgh ME (2003) Nitrogen metabolism and recycling in Holstein heifers. J Anim Sci 81, 545-552.

26. Archibeque SL, Burns JC \& Huntington GB (2002) Nitrogen metabolism of beef steers fed endophyte-free tall fescue hay: effects of ruminally protected methionine supplementation. J Anim Sci 80, 1344-1351.

27. Cocimano MR \& Leng RA (1967) Metabolism of urea in sheep. Br J Nutr 21, 353-371.

28. Bunting LD, Boling JA \& MacKown CT (1989) Effect of dietary protein level on nitrogen metabolism in the growing bovine: I. Nitrogen recycling and intestinal protein supply in calves. J Anim Sci 67, 810-819.

29. Thornton RF (1970) Factors affecting the urinary excretion of urea nitrogen in cattle II. The plasma urea nitrogen concentration. Aust J Agric Res 21, 145-152.

30. McIntyre KH (1971) The effects of continuous intravenous and intraruminal infusion of urea on nitrogen metabolism in sheep. Aust J Agric Res 22, 429-441.

31. Neutze SA, Kellaway RC \& Faichney GJ (1986) Kinetics of nitrogen transfer across the rumen wall of sheep given a lowprotein roughage. Br J Nutr 56, 497-507.

32. Ouellet DR, Demers M, Zuur G, Lobley GE, Seoane JR, Nolan JV \& Lapierre H (2002) Effect of dietary fiber on endogenous nitrogen flows in lactating dairy cows. $J$ Dairy Sci 85, $3013-3025$. 